\title{
Model of advanced training of physics teachers at the present stage
}

\author{
Svetlana Kholina ${ }^{1, *}$, Oksana Babenko ${ }^{1}$, Viktoriya Grudinina $^{1}$, Victor Velichkin ${ }^{1}$ \\ ${ }^{1}$ Moscow State Region University, 10A, st. Radio, 105005, Moscow, Russia
}

\begin{abstract}
This article discusses a model for training future physics teachers. The conceptual model of training future physics teachers shows the complete structure of training, methodological features of training for professional activity, future physics teachers at different stages of training: bachelor's, master's, postgraduate and professional retraining. The methodological features of the training consist in the examples of introduction of physical concepts. The article presents the evidence base for the effectiveness of the methodological system of training future physics teachers for secondary schools, lyceums and gymnasiums in the Moscow region. The article presents an approbation of the results of objective assessment of the quality of training of physics teachers, based on the results of research activities of students, achievements in all-Russian educational competitions and participation in the International competition "WorldSkills". Interaction of the Department and faculty is carried out with secondary schools, lyceums, gymnasiums, higher educational institutions in the framework of scientific and practical, scientific and methodological conferences for schoolchildren, students, teachers and teaching staff. The article highlights the factors that affect the success of training physics teachers, examples of which are: fruitful interaction with the external environment, both directly with the personal participation of representatives of educational institutions, and through networking; continuous monitoring to assess the success of teaching activities by graduates of this field of training; improving the quality of student recruitment, through the annual holding of physics Olympiads for students of secondary schools in the Moscow region.
\end{abstract}

\section{Introduction}

Modern education is undergoing many changes. The requirements of the new generation of educational standards are aimed at the formation of professional competencies for future physics teachers, bachelor's, master's, post-graduate students and students of professional retraining. Curricula and work programs are constantly analyzed and adjusted in order to monitor the objectivity and effectiveness of the proposed educational training of future physics teachers at different levels: bachelor's, master's, postgraduate, professional retraining.

*Corresponding author: sa.kholina@mgou.ru 
The problem of our research is to find the most perfect model for training future physics teachers, including the correct selection of academic disciplines in the variable part of the educational curriculum, the content of academic disciplines of the professional block. And most importantly, the methods and approaches used in the study of these disciplines.

The practical significance of our research lies in the application of new methods and approaches used in the educational process when teaching physics by teachers in secondary educational institutions.

The results of testing of our research have been repeatedly shown in publications of journals included in the list of the Higher attestation Commission, in international articles, as well as reported at conferences of various levels, International, National, and Regional.

\section{Methods}

The modernization of the physics education system in Russia can yield positive results if the professional training of future physics teachers is improved, which is consistent with the main objectives of the project "Young professionals", implemented within the framework of the national project "Education". The model for training future physics teachers shows the main stages (Fig. 1):

- mastering by students - future teachers of physics the content of academic disciplines and elective methodological module;

- practical training;

- implementation of independent work;

- participation in scientific and research activities.

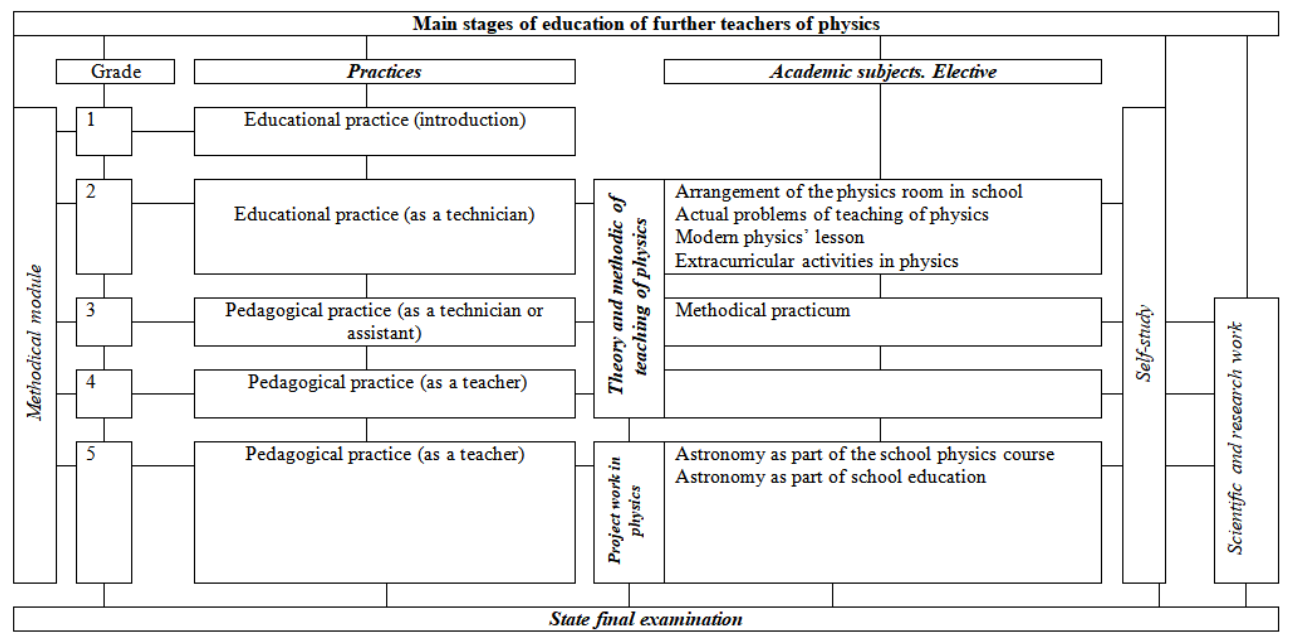

Fig. 1. Model of education of further teachers of physics.

Training of future physics teachers with an additional specialty "computer Science" is carried out by the University for five years. During this period, students master academic disciplines and electives within the framework of the methodological module, the main purpose of which is to study various subject areas of the theory and methodology of teaching physics. At all stages of training, theoretical training of future teachers is combined with practical training both at the University and in educational organizations. Practices are an integral part of the practice-oriented development of the theory and methodology of teaching physics. Independent work of students is an important part of professional training. It organically combines the formation of skills and mastering the basic competencies of a modern physics teacher that meet the requirements of the 
professional standard of the teacher. Scientific and research activities are carried out by students mainly from the third year of study in the framework of practices, academic disciplines and elective courses. The results of this work become the main part of the methodological part of the final qualification work and pedagogical experiment.

An important component of the methodological module is the academic discipline "Theory and methods of teaching physics". Its contents are:

- General questions of teaching physics at school;

- special issues of studying mechanical, thermal, electromagnetic, and quantum phenomena in primary school (grades 7-9);

- special issues of studying mechanics, molecular physics, electrodynamics, quantum physics in high school (grades 10-11);

- elements of astronomy and astrophysics in the content of the school physics course;

- system of physical experiment in the course of basic and secondary school physics;

- system of tasks of the school course of physics;

- methods for solving physical problems.

Special attention is paid to the method of introduction of concepts. Thus, when studying thermal conductivity, there are a number of difficulties when working with the system of tasks in a school physics textbook, which can be excluded when analyzing possible responses from students. A frequently asked question is related to the protection of humans and animals from the cold. When formulating the answer, students use the teaching material of the physics textbook, which indicates materials with poor thermal conductivity. These include wool, pen, paper, and other porous bodies, between the fibers of which there is air that does not conduct heat well. However, the question arises: why in the absence of fur, down, feathers, warm clothing, animals, birds, people will be cold? After all, in this case, the skin is in contact with air, and air is a poor conductor of heat. However, we are cold. Students can come to this conclusion. The attention of future physics teachers should be drawn to the fact that the main types of heat transfer from animal and human bodies to the surrounding air are convection and radiation, and not thermal conductivity [2]. The presence of fur, etc. suppresses the convection of air from the body to the environment, since air molecules have to "Wade" through a dense "forest" of fibers, villi that make up such substances.

A similar situation arises when discussing the problem of preserving winter crops from freezing with the help of snow. Due to the fact that there was air above the ground before the snowfall, heat transfer from the ground to the air was mainly due to natural convection and radiation, and not due to thermal conductivity. The snow that falls suppresses convection and reflects radiation from the ground back into the ground. The thermal conductivity remains, which is not intensive, since deep loose snow is a porous substance.

The same should be the answer to the question about not freezing in winter in rivers and lakes of water that is under a thick layer of ice. Ice reflects radiation from the water back, and air convection from the water is excluded, since there is ice between them. Finally, because the coefficient of thermal conductivity of ice is small, the difference between the higher surface temperature of ice in contact with water and the lower surface temperature of ice in contact with atmospheric air will be significant (for example, $0^{\circ} \mathrm{C}$ and $-20^{\circ} \mathrm{C}$, respectively). That's why the water doesn't freeze. In connection with the above, it should be noted that these issues are more appropriate to consider after studying all types of heat transfer.

This approach to conducting lectures contributes to the formation of a high level of methodological training of future physics teachers.

The structure of teaching activities in schools is studied in the system of higher professional education. In-depth study of this issue is one of the conditions for the effective formation of a highly educated, multilaterally developed pedagogical specialist from a 
student. Due to the constant development of social Sciences, multiple growth in the volume of information available for study and increasing requirements for the quality of students ' education, teachers must constantly improve their skills and acquire new scientific knowledge. Although a high school teacher has some creative freedom in choosing methods and methods of delivering educational material, he must comply with the most important requirements of the principles and methods of teaching. These requirements allow you to form the content, organization and methodology of the entire educational process.

The discipline "Modern physics lesson" in high school allows you to study the methodology of organizing a physics lesson in primary and secondary schools in accordance with the requirements of the Federal State educational standard. In the course of studying the discipline, the basic principles and concepts of building a physics lesson are mastered, and the features of pedagogical technologies are determined based on the activation of cognitive activity implemented in physics lessons. In practical classes, the technology of conducting physics lessons is considered, the content of the physics course and the system of physical experiment in primary and secondary schools are analyzed, and the forms and methods of controlling the results of students in the physics lesson are identified.

Such tasks are more effectively solved by a high school teacher with experience in high school. Practical teachers with more than 25 years of teaching experience note that the time requirement is to prepare students of the pedagogical direction to perform the functions of teaching and education, taking into account their personality, the expected learning results, the ability to manage the process of learning and education, the amount of knowledge and experience. The most important condition for the formation of the future teacher's personality is the existence of an educational space [3], in which it is possible for each student to systematically form their abilities based on the balance of internal contradictions of "want" and "can". This space of educational activity is created in the creative community of the teacher and students.

Although the learning process is shaped by certain motives, goals, and means, it can end with results that may differ from the teacher's expectations. The educational process, in the presence of many individuals of students, should lead to a "common denominator", to the established requirements of the regulatory framework of activities that the teacher knows and sets. Thus, there is some contradiction between the norm of activity that the teacher plans and sets in this lesson, and the norm of activity of each particular student.

There is a famous saying of Confucius: "Three paths lead to knowledge: the path of reflection is the noblest path; the path of imitation is the easiest path; and the path of experience is the bitterest path." The teacher in his work goes through all these paths simultaneously. This is a strict requirement for this profession, in connection with which the teacher must have managerial knowledge. Managing the learning process is necessary at any stage of the lesson. The basis of management is the system design of the student's cognitive activity, and its essence is a step - by-step introduction to cognitive activity. Taking into account the specifics of the object and subject of work, the personal and business qualities of the teacher merge into a single psychological and pedagogical competence. The teacher's understanding of the purpose, meaning, purpose of their work, their self-esteem, affect not only their own professional self-determination and formation, but also the culture, value orientations, moral standards, needs and abilities of the person they are educating.

It is possible to distinguish the knowledge that a school teacher should possess at a high professional level - to know the content of the subject, teaching methods, methods and techniques of individual and differentiated learning, promising areas of development in the field of education. 
For students, it is useful to have a clear presentation of the teaching material by the teacher, transfer of accumulated experience and thoughts, taking into account the requirements of the work program of the discipline. The teacher must objectively evaluate knowledge, create an atmosphere of cooperation, and arouse interest in the discipline being studied.

In practical classes, students learn how to build the structure of the lesson, choose the right form of presentation of material for deep learning of the ideas of modern physics and the system of scientific concepts. A modern schoolchild should possess the knowledge they receive, be well-versed in scientific and technical literature, be able to independently and quickly find the necessary information, systematically Supplement it and actively, creatively apply it. This task can be solved by activating the cognitive activity of students, developing non-standard forms of thinking and creative potential in the learning process.

The most effective way to activate students ' thinking is problem-based learning, which focuses on the development of technology maps and lesson plans with elements of a problematic nature. To consolidate and control the quality of learning, it is recommended to select practice-oriented tasks, and to develop the creative potential of students - to strive to apply elements of project activity in the lessons.

The educational model of training future physics teachers includes, in addition to basic training of physics teachers, the implementation of advanced training courses for current physics teachers in secondary schools, lyceums, and high schools in the Moscow region. Modern educational requirements reflect continuity at all levels of education.

The huge information flow and the possibility of receiving online courses, online conferences, and the possibility of organizing educational chats make us think about the need and search for new approaches and methods in teaching, in designing the educational model of future physics teachers, taking into account the continuity, constant improvement of curricula, work programs, forms of organization, methods and approaches.

The conceptual model of training consists in the selection of professional disciplines, content material for study [4] at all levels of educational activity.

\section{Results}

The Department constantly monitors educational activities to assess the quality and effectiveness of teaching physics, both for bachelors, masters, postgraduates, and physics teachers. The objectivity of the assessment of the monitoring carried out for the effectiveness of training physics teachers lies in the constant interaction with the external environment, educational institutions, one of which is the art and technical Lyceum of Vidnoye, Lyceum no. 26. Podolsk, Lyceum no. 15 Mytischi and others. On the basis of the above-mentioned educational institutions, pedagogical experiments are carried out during the testing of diploma, master's, postgraduate and dissertation research. Scientific and practical cooperation is carried out not only with secondary educational institutions, but also with Higher educational institutions, among which are the Lomonosov Moscow state University (faculty of physics), the Moscow Institute of physics and technology (national research University) and others. The results of fruitful cooperation are reflected in scientific publications, the authors of which are not only teachers of the Department of methods of teaching physics, but also teachers and professors of other Higher educational institutions, such as the Lomonosov Moscow state University. The results of pedagogical experiments are presented at conferences of various levels, International, National and Regional. Every year, the Department conducts a scientific and methodological conference, the result of which is a collection of scientific articles, which is included in the database of the Russian scientific citation index (RSCI). Also, based on the results of the conference, the most relevant, priority problems and ways to solve them are selected, which are reflected in 
journal articles recommended by the Higher attestation Commission (HAC) and international articles [5].

In the framework of cooperation with higher education institutions, students hear lectures, master classes by professors of leading universities such as Moscow state University, Moscow Institute of physics and technology.

Repeatedly and effectively, students take part in International and all-Russian educational competitions, scientific and practical conferences. They are prize-winners and laureates. Students took part in the international competition "WorldSkills". Research activities of students are based on the introduction and improvement of pedagogical approaches, methods and educational technologies in teaching physics in primary, secondary and specialized schools [1]. The results of research activities are reflected in the final qualifying papers, scientific articles. The pedagogical experiment is tested during the course of pedagogical practice in secondary schools at physics lessons [5]. The research activities of students according to the 2018-2019 academic year are presented in table 1 .

Table 1. The results of research activity of students, further teachers of physics.

\begin{tabular}{|c|c|c|c|}
\hline $\begin{array}{l}\text { Types of students' } \\
\text { research activities }\end{array}$ & $\begin{array}{c}\text { Training direction, } \\
\text { training profile, } \\
\text { course }\end{array}$ & Student's full name & Result \\
\hline $\begin{array}{l}\text { International } \\
\text { competition } \\
\text { «WorldSkills » }\end{array}$ & $\begin{array}{l}44.03 .05 \\
\text { "Pedagogical } \\
\text { education", } \\
\text { training profile } \\
\text { "Physics } \\
\text { computer science", } \\
\text { 4th year }\end{array}$ & E.S. Yakunina & $\begin{array}{ll}\text { Certificate } & \text { of } \\
\text { participation } & \end{array}$ \\
\hline $\begin{array}{l}\text { National } \\
\text { educational } \\
\text { program } \\
\text { «Intellectual and } \\
\text { creative potential of } \\
\text { Russia» }\end{array}$ & $\begin{array}{lr}44.03 .05 & \\
\text { "Pedagogical } \\
\text { education", } \\
\text { training } \\
\text { "Physics } \\
\text { computer } & \text { science", } \\
\text { 5th year } & \\
\end{array}$ & A.V. Migunova & $\begin{array}{l}\text { Winner of the first } \\
\text { degree in the category } \\
\text { "research and project } \\
\text { activities of students» }\end{array}$ \\
\hline $\begin{array}{l}\text { All-Russian } \\
\text { physical } \\
\text { technical and } \\
\text { «Come outrol } \\
\text { solve!» }\end{array}$ & $\begin{array}{lr}44.03 .05 & \\
\text { "Pedagogical } \\
\text { education", } \\
\text { training } \\
\text { "Physics } \\
\text { computer } \\
\text { 4th year }\end{array}$ & $\begin{array}{l}\text { N.A. Kulchinskaya } \\
\text { E.S. Yakunina } \\
\text { A.A. Lutz } \\
\text { S.I. Guseynova } \\
\text { M.A. Nadakhovskaya } \\
\text { S.A. Kovaleva } \\
\text { E.I. Ivleva } \\
\text { A.M.Kovaleva }\end{array}$ & 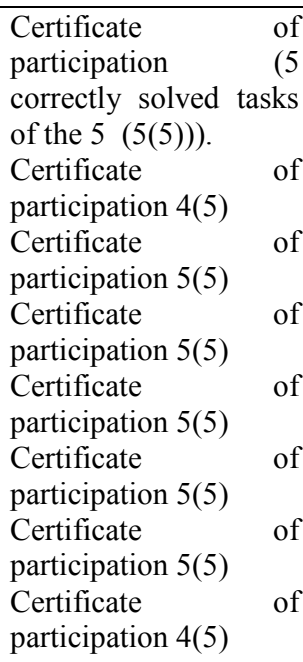 \\
\hline $\begin{array}{l}\text { Reports of the } \\
\text { scientific } \\
\text { practical conference }\end{array}$ & $\begin{array}{l}44.03 .05 \\
\text { "Pedagogical } \\
\text { education", } \\
\end{array}$ & $\begin{array}{l}\text { E.M. Mezhakova } \\
\text { A.V. Migunova } \\
\text { C.M. Grudtsina } \\
\end{array}$ & Article \\
\hline
\end{tabular}




\begin{tabular}{|c|c|c|c|}
\hline $\begin{array}{lr}\text { "Problems } & \text { and } \\
\text { prospects } & \text { of } \\
\text { development } & \text { of } \\
\text { education } & \text { in } \\
\text { physics", April } & 11- \\
12,2018 & \\
\end{array}$ & $\begin{array}{lr}\text { training } & \text { profile } \\
\text { "Physics } & \text { and } \\
\text { computer } & \text { science", } \\
\text { 4th year } & \end{array}$ & V.V. Nikanorova & \\
\hline $\begin{array}{l}\text { Reports of the } \\
\text { scientific } \\
\text { practical conference } \\
\text { "Problems } \\
\text { prospects and } \\
\text { development } \\
\text { education } \\
\text { physics", April } \\
12,2018\end{array}$ & $\begin{array}{l}44.03 .05 \\
\text { "Pedagogical } \\
\text { education", } \\
\text { training } \\
\text { "Physics profile } \\
\text { computer } \\
\text { 3rd year }\end{array}$ & $\begin{array}{l}\text { E.I. Ivleva, M.A. } \\
\text { Nadakhovskaya, } \\
\text { E.S. Yakunina }\end{array}$ & Article \\
\hline $\begin{array}{lr}\text { Reports of the } \\
\text { scientific } \\
\text { practical conference } \\
\text { "Problems } \\
\text { prospects } \\
\text { development } \\
\text { education } \\
\text { physics", April } \\
11,2019 \text { of } \\
\text { 11, } \\
\end{array}$ & $\begin{array}{l}4.03 .05 \\
\text { "Pedagogical } \\
\text { education", } \\
\text { training profile } \\
\text { "Physics } \\
\text { computer science", } \\
\text { 5th year }\end{array}$ & $\begin{array}{l}\text { V.V. Nikanorova } \\
\text { S.M. Chebotareva } \\
\text { A.V. Migunova } \\
\text { V.V. }\end{array}$ & Article \\
\hline $\begin{array}{lr}\text { Reports of the } \\
\text { scientific } \\
\text { practical conference } \\
\text { "Problems } \\
\text { prospects } \\
\text { development } \\
\text { education } \\
\text { physics", April } \\
11,2019 \text { of } \\
\text { 11, } \\
\end{array}$ & $\begin{array}{l}44.03 .05 \\
\text { "Pedagogical } \\
\text { education", } \\
\text { training profile } \\
\text { "Physics } \\
\text { computer science", } \\
\text { 4th year }\end{array}$ & $\begin{array}{l}\text { S.I. Guseynova } \\
\text { M.A. Nadakhovskaya } \\
\text { Y.A. Lukyanenko } \\
\text { E.S. Yakunina S.A. } \\
\text { Kovaleva } \\
\text { E.I. Ivleva } \\
\text { N.A. Kulchinskaya }\end{array}$ & Article \\
\hline $\begin{array}{lr}\text { Reports of the } \\
\text { scientific } \\
\text { practical conference } \\
\text { "Problems } \\
\text { prospects } & \text { and } \\
\text { development } & \text { of } \\
\text { education } & \text { in } \\
\text { physics", April } & 10- \\
11,2019 & \end{array}$ & $\begin{array}{l}44.03 .05 \\
\text { "Pedagogical } \\
\text { education", } \\
\text { training profile } \\
\text { "Physics r and } \\
\text { computer science", } \\
\text { 3rd year }\end{array}$ & $\begin{array}{l}\text { D.A. Ermakova } \\
\text { A.R. Onishin }\end{array}$ & Article \\
\hline
\end{tabular}

The table of results of research activities of students does not shows the results of undergraduates and postgraduates.

\section{Discussion}

The entire volume of professional training of physics teachers cannot be shown in a single article, but some features, in our opinion, more significant, we will present in the following presentation.

One of the most important problems is the selection of applicants who enter our University to get a qualification-a teacher of physics and computer science. The solution to this problem is the implementation of the Department of annual physics Olympiads to attract the most qualified and professionally interested graduates of General education institutions. 
The results of scientific work of undergraduates and postgraduates are reflected.

\section{Conclusion}

The presented model of training of future physics teachers makes it more likely to assert that graduates of the pedagogical direction of training have a high level of formation of professional competencies necessary for a teacher of a modern school.

\section{References}

1. O. Babenko, Vestnik of Moscow State Regional University. Series: Pedagogical 2, 102 (2017)

2. V. Velichkin, Legacy of Nadezhda Krupskaya and present: Scientific work of Russian science-practical conference in memory of 150-anniversary of Nadezhda Krupskaya (M., MANPO, 2019)

3. V. Grudinina, Vestnik of Moscow State Regional University. Series: Pedagogical, 237 (2017)

4. S. Kholina, Pedagogical studying and science 6, 57 (2015)

5. O. Babenko, V. Larionov, O. Khanchich, SHS Web of Conferences 29, 02001 (2016) 